\title{
Early Patterns of Faculty Compensation for Developing and Teaching Distance Learning Courses
}

\author{
Gary A. Berg \\ Chapman University and Claremont Graduate University \\ 16811 Vincennes Street \\ North Hills, CA 91343 \\ Phone: (714) 532-6049 \\ FAX: (714) 997-6641 \\ E-mail: gberg@,chapman.edu
}

\begin{abstract}
This paper is an investigation into compensation practices for faculty developing and teaching distance learning courses. The research divides itself into two basic lines of inquiry: direct and indirect compensation (including royalties, training, and professional recognition). Also, economic models for distance learning are examined with a view towards understanding faculty compensation within attempts to reduce labor costs. The primary questions this research attempts to answer are: What are the current policies and practices in higher education for compensating faculty who develop and teach distance learning format courses? Will the increased use of distance learning format courses alter overall labor conditions for American faculty? If so, how? Although information is limited, it is found that faculty work in both developing and teaching distance learning format courses tends thus far in this early stage to be seen as work-for-hire under regular load with little additional indirect compensation or royalty arrangements.
\end{abstract}

\section{KEY WORDS}

Distance Learning Courses, Faculty Compensation, Distance Learning Economics

\section{INTRODUCTION}

This paper is an investigation into the standards and practices of compensation for faculty developing and teaching distance learning courses in higher education. The research divides itself into two basic lines of inquiry: direct and indirect compensation rates. The indirect compensation question involves much larger questions having to do with principles of intellectual property and copyright, which are beyond the scope of this paper. However, a sense of the trends and the early approaches in relationship to royalty structures for the development of distance learning courses are examined with a view towards understanding how they may affect overall compensation. Economic models for distance learning including capital for labor and labor for labor models are studied with a view towards understanding faculty compensation within these structures. The primary questions this research attempts to answer are: what are the current policies and practices in higher education for compensating faculty who develop and teach distance learning format courses? Will the increased use of distance learning format courses alter the compensation rate for American faculty? If so, how? 


\section{Importance}

Why are these important questions? Distance learning is on the rise in higher education. In 1995, the National Center for Education Statistics conducted a Survey on Distance Education Courses offered by Higher Education Institutions and found a third of the institutions offered distance education courses, and another quarter planned to offer such courses in the next three years [1]. Maitland and Rhoades [2] report an increase of 8\% from 1994 to 1997-98 in the number of university faculty contracts with provisions about technology, while another study [3] found a $9 \%$ increase in mean distance learning enrollments from spring 1998 to fall 1998. A recent catalogue of distance learning courses lists 13,000 distance courses taught at 140 accredited schools and institutions [4]. While the percentage of overall higher education courses is still small, multiple factors are leading to an increase in the use of distance learning format courses in the academy. Furthermore, the majority of distance learning courses are developed by faculty, not commercial providers. Three-quarters of the higher education institutions that offered distance education courses in fall 1995 used distance education course curricula developed by the institution's subject area departments or schools [1]. With the majority of these distance learning courses developed by faculty members, clearly this represents a potentially new or altered form of employment likely to impact traditional faculty roles. If distance learning format courses reduce or increase faculty compensation this is likely to have long-term affects on faculty, and by extension, higher education as a whole.

\section{ECONOMIC MODELS FOR DISTANCE LEARNING}

It is useful to look at economic models of distance learning to better understand the forces shaping faculty compensation. While often it is debated whether or not distance learning in America is profitable, according to the Primary Research Group [3] 86.96\% of the distance learning programs surveyed make a profit as shown in Table 1 [ 3 (p. 103)]:

\begin{tabular}{|l|c|c|c|c|c|}
\hline & $\begin{array}{c}\text { Less than } \\
10 \%\end{array}$ & $\begin{array}{c}\text { From } 11 \% \text { to } \\
30 \%\end{array}$ & $31 \%$ to $50 \%$ & $\begin{array}{c}\text { Greater than } \\
50 \%\end{array}$ & Loss \\
\hline All colleges & $28.26 \%$ & $32.61 \%$ & $13.04 \%$ & $13.04 \%$ & $13.04 \%$ \\
\hline
\end{tabular}

Table 1. Reported Profit Margins of Distance Learning Programs.

How are distance learning programs structured so that they can be profitable?

\section{Differences in Types of Distance Learning}

Bates [5] argues that each type of distance learning has a different economic model. Broadcast and computer-based learning are more expensive per student study hour, while print-based and online forms are less expensive up front. However, after 1,000 students the expense variance among the types of distance learning formats narrows considerably. Although there are differences in the economics among the types of technologies used in distance learning, they all involve to varying degrees the following two basic approaches to faculty: replacement of labor with capital, or replacement of faculty with cheaper labor.

\section{A. Capital Replacing Labor}

John Daniel, Vice-Chancellor of the British Open University, claims that the basic economic approach of distance learning is to replace labor with capital, or to replace variable costs with fixed costs. He proposes that the per unit cost of teaching can be cut either by adding more students to existing courses or by making instruction more efficient [] ]. In Figure 1 [ $\underline{6}$ (p. 62)], 
Daniel shows the point at which volume is large enough for distance learning courses to be more productive than traditional courses by replacing labor with fixed cost capital.

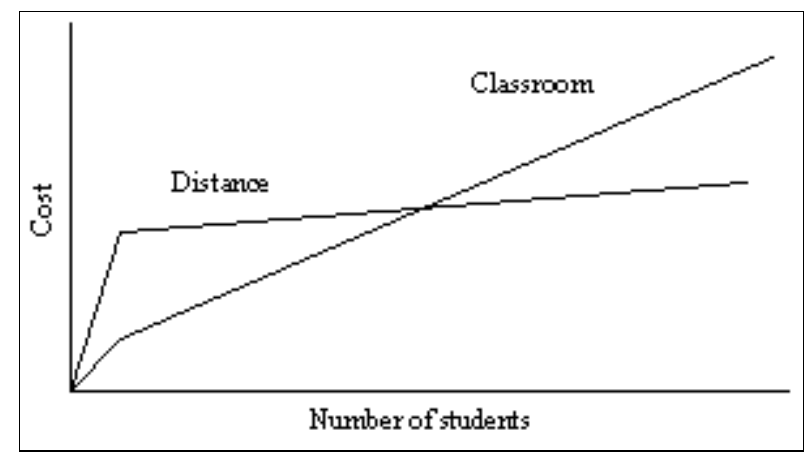

Figure 1. Schematic Representation of the Growth in Institutional Cost With Student Numbers for the Distance Learning and Classroom Teaching.

The British Open University claims that it has used this model to reduce faculty labor costs from $66 \%$ to $20 \%$ of the total budget [ $[5]$.

In the United States, economic models for distance learning in higher education at the degree level are still being developed. Some [7], [ [ ] follow Daniel in arguing that distance learning offers economies of scale after an up-front capital investment. They claim that savings can only be realized by reducing personnel costs (estimated at $70-80 \%$ of total expenses). They too see the solution in finding ways to substitute capital for labor. There is some evidence that this may be occurring. Table 2 [ $\underline{3}$ (p. 105)] shows the Primary Research Group's [ 3 ] finding that instructor/tutor salaries account for only $31.72 \%$ of the distance learning program expenses in their survey.

\begin{tabular}{|c|c|c|c|c|}
\hline & Mean & Median & Minimum & Maximum \\
\hline All colleges & $\begin{array}{c}31.72 \\
\%\end{array}$ & $30.0 \%$ & $10.0 \%$ & $85.0 \%$ \\
\hline
\end{tabular}

Table 2: Percentage of the Total Cost and Expenditures Attributed to Instructor/Tutor Salaries.

However, are distance learning programs reducing the amount of faculty labor in American higher education? Some [6], [7] point out that in practice technology is often added to a fixed faculty cost thereby only adding expense to the total budget. Metlitzky [9] surveyed faculty and found faculty disagree with the notion that technology reduces the faculty workload, confirming the impression that labor is not currently being reduced by the forms of distance learning being utilized in the United States. Consequently, it is unclear as to whether or not the model of replacing labor with capital is leading to a reduction in faculty workload in American higher education.

\section{B. Cheap Labor Replacing Expensive Labor}

The second basic approach, a labor for labor model, is to divide the faculty role into segments and reduce the total labor cost by replacing higher priced faculty with less expensive labor. Jewett [10] identifies three basic functions of faculty in a cost analysis: preparation, presentation and interaction/assessment. To the degree that these functions can be performed individually by less 
expensive labor, the overall cost will be reduced. The British Open University divides up these functions with course design teams and 7,000 part-time tutors (associate lecturers) whose tasks are to provide academic support to local groups of students [6]. Daniel [6 (p. 63)] cites Snowden and Daniel [11] for an equation that expresses this division of faculty roles:

$$
\mathrm{C}=\mathrm{a} 1 \mathrm{x} 1+\mathrm{a} 2 \mathrm{x} 2+\mathrm{by}+\mathrm{c}
$$

Where:

$\mathrm{C}=$ total cost;

a1 $=$ course development cost per credit;

$\mathrm{x} 1=$ course credits in development

$\mathrm{a} 2=$ course $\mathrm{revision} /$ maintenance/replacement costs per credit;

$\mathrm{x} 2=$ course credits in delivery;

$\mathrm{b}=$ delivery costs per course enrollment;

$y=$ course enrollments;

$\mathrm{c}=$ institutional overheads.

What is telling in this formula is that there is no separate symbol for faculty compensation. Faculty expenses are spread amongst development, maintenance and delivery costs, and in this way the formula represents the way in which the faculty expense is dispersed in the economic model. In America, Arvan et. al. [12] argue for a labor-for-labor model, similar to the British model.

These distance learning economic models show that faculty rates of compensation and duties may be affected by either substituting labor with capital, or by substituting faculty with less expensive labor performing current faculty tasks. With this understanding of the economics of distance learning, the more refined questions then are to what degree at present in American higher education is 1) faculty labor being replaced by capital? 2) faculty replaced by less expensive labor performing roles traditionally performed by faculty?

\section{COMPENSATION DATA}

\section{A. Data Sources}

The data on compensation of faculty for the development and teaching of distance learning courses in American higher education is limited. Two surveys provided the greatest amount of data: the "Faculty Compensation and Support Issues in Distance Education," published by the Instructional Telecommunications Council (ITC) [13], and the National Education Association (NEA) survey of "Bargaining Technology Issues in Higher Education" [14]. Additionally, the "Campus Computing 1998" survey [15] and "The Survey of Distance Learning Programs in Higher Education" [3] provide some useful data as well. Distance learning is defined differently (or not at all) in the various data sources. The ITC survey identifies four different formats of distance education delivery: live interactive video/audio, pre-packaged video/audio, modembased, and print-based. Since the NEA data is from a collection of bargaining agreements, definitions of distance learning vary greatly, and often in a vague manner.

\section{ITC Survey}

During the spring of 1996, ITC surveyed its membership in four main areas: faculty compensation, intellectual property rights, support services and professional development. One hundred sixteen completed surveys represented a $23.2 \%$ return rate. As the membership of ITC 
was surveyed, this is not a random sample. Since the organization focuses on educational telecommunications, there is a clear bias towards video-based courses. Furthermore, $94.7 \%$ of the respondents were from community colleges, $97.3 \%$ from public institutions.

\section{NEA Survey}

This survey was taken from the 1998-99 release of NEA's Higher Education Contract Analysis System (HECAS) which includes over 500 higher education contracts with an ability to search on specific words or phrases. A total of 126 two- and four-year institutions are included in the survey of "distance learning" and "intellectual property" clauses in collective bargaining agreements. Out of 64 agreements that mention compensation rates, 12 are higher education institutions. Of the 69 agreements with clauses dealing with intellectual property rights, 16 are higher education institutions. As opposed to the ITC survey, the NEA data are a collection of abstracts from agreements rather than direct responses to questions from institutional representatives. Consequently, the compiling of data involved a degree of interpretation, and some unreliability. Effort was taken to adequately represent individual agreements by categorization, but this was not always a simple matter. Additionally, the categories for both direct and indirect compensation are not mutually exclusive and many institutions included contractual language that required multiple affirmative responses.

\section{Primary Research Group, Inc., Survey}

This survey data is based on a random sample of 61 college and university distance learning programs throughout the United States and Canada. The survey sample included 44 programs in public universities and 17 in independents; 32 programs were from 2-year institutions, and 29 from 4year institutions. The data is presented in the aggregate and by type (public/private), level of the college (two-year/four-year) and number of students enrolled in the program.

\section{Campus Computing 1998 Survey}

The "Campus Computing 1998: The Ninth National Survey of Desktop Computing and Information Technology in Higher Education" focuses more broadly on the use of technology in higher education, but does include some data relevant to issues of compensation for faculty that give an overview of the institutional trends. The survey was designed to collect information about campus planning, policies, and procedures affecting the use of computers in higher education. A random sample of public and private two-and four-year colleges and universities was done. Out of 1,623 institutions that were invited, 571 responded to the survey.

\section{B. Survey Results}

We are in an early stage of development of policy regarding compensation for teaching and developing distance learning courses. In the NEA collection of contract excerpts, 9 out of 64 indicated plans to form a committee or task force to study the compensation and intellectual property right issues involved in distance learning. In a section of the Campus Computing Survey [15] dealing with Academic and Instructional Computing Policies and Procedures the questions shown in Table 3 [15 (p.12)] are asked and answered: 


\begin{tabular}{|c|c|c|c|c|c|c|c|}
\hline \multirow{2}{*}{$\begin{array}{l}\text { General campus policies } \\
\text { about desktop computers }\end{array}$} & \multirow{2}{*}{$\begin{array}{l}\text { All } \\
\text { cam- } \\
\text { puses }\end{array}$} & \multicolumn{2}{|c|}{ Universities } & \multicolumn{2}{|c|}{ 4-year Colleges } & \multicolumn{2}{|c|}{ 2-year Colleges } \\
\hline & & Public & Private & Public & Private & Public & Private \\
\hline \multicolumn{8}{|c|}{$\begin{array}{l}\text { Academic \& instructional computing policies and procedures } \\
\text { Does your campus/institution have/provide: }\end{array}$} \\
\hline $\begin{array}{l}\text { Plan for integrating IT into the } \\
\text { curriculum }\end{array}$ & 40.4 & 44.1 & 43.5 & 39.1 & 36.1 & 44.3 & 42.9 \\
\hline $\begin{array}{l}\text { Projects for developing desktop } \\
\text { instructional software/courseware }\end{array}$ & 55.4 & 83.1 & 82.6 & 64.8 & 47.4 & 46.8 & 33.3 \\
\hline $\begin{array}{l}\text { Support for faculty developing } \\
\text { instructional software/courseware }\end{array}$ & 69.8 & 91.5 & 91.3 & 78.2 & 58.5 & 69.0 & 47.6 \\
\hline $\begin{array}{l}\text { Support for faculty developing } \\
\text { software for their research }\end{array}$ & 36.2 & 63.2 & 47.8 & 52.7 & 30.6 & 24.2 & 4.8 \\
\hline $\begin{array}{l}\text { Program for rewarding courseware } \\
\text { development }\end{array}$ & 27.8 & 38.6 & 17.4 & 36.4 & 23.4 & 26.9 & 9.5 \\
\hline $\begin{array}{l}\text { Resource center focusing on use of } \\
\text { IT }\end{array}$ & 61.9 & 93.2 & 78.3 & 72.5 & 52.1 & 57.0 & 23.8 \\
\hline $\begin{array}{l}\text { Agreements/licenses for duplication } \\
\text { of software products }\end{array}$ & 54.0 & 86.4 & 69.6 & 69.1 & 51.8 & 35.2 & 23.8 \\
\hline $\begin{array}{l}\text { Plan for using internet resources in } \\
\text { instruction }\end{array}$ & 33.3 & 31.0 & 31.8 & 27.5 & 33.7 & 38.2 & 28.6 \\
\hline $\begin{array}{l}\text { Plan for using internet resources in } \\
\text { distance education }\end{array}$ & 29.5 & 36.2 & 34.8 & 34.9 & 17.3 & 39.4 & 14.3 \\
\hline Plan for using internet for marketing & 47.1 & 47.5 & 43.5 & 44.4 & 53.6 & 40.5 & 52.4 \\
\hline $\begin{array}{l}\text { Program to reward use of IT in } \\
\text { review/promotion process }\end{array}$ & 12.9 & 8.8 & 13.0 & 15.6 & 14.7 & 10.9 & 9.5 \\
\hline $\begin{array}{l}\text { Maintain library of academic } \\
\text { courseware }\end{array}$ & 22.2 & 29.8 & 8.7 & 30.3 & 19.4 & 20.6 & 9.5 \\
\hline $\begin{array}{l}\text { Program assessing the impact of IT } \\
\text { on instruction }\end{array}$ & 13.1 & 24.1 & 34.8 & 12.0 & 9.9 & 10.4 & 14.3 \\
\hline $\begin{array}{l}\text { Policy regarding ownership of } \\
\text { WWW-based resources developed } \\
\text { by faculty }\end{array}$ & 23.3 & 38.6 & 30.4 & 27.5 & 14.1 & 27.3 & 4.8 \\
\hline
\end{tabular}

Table 3. Campus Computing, 1998.

One can see from Table 3 [15 (p.12)] that policies regarding faculty work in distance learning still need to be formulated at many institutions.

\section{Direct Compensation}

There are two major types of direct compensation: compensation for teaching a distance learning course, and compensation for developing a distance learning course. The compensation for developing a course should be seen in stipend or other payments beyond regular or overload status. 
The findings of the ITC survey for full-time faculty compensation for teaching prepackaged courses showed payment by regular load with normal enrollments as receiving the highest response rate as shown in Figure 2 [13 (p. 13)].
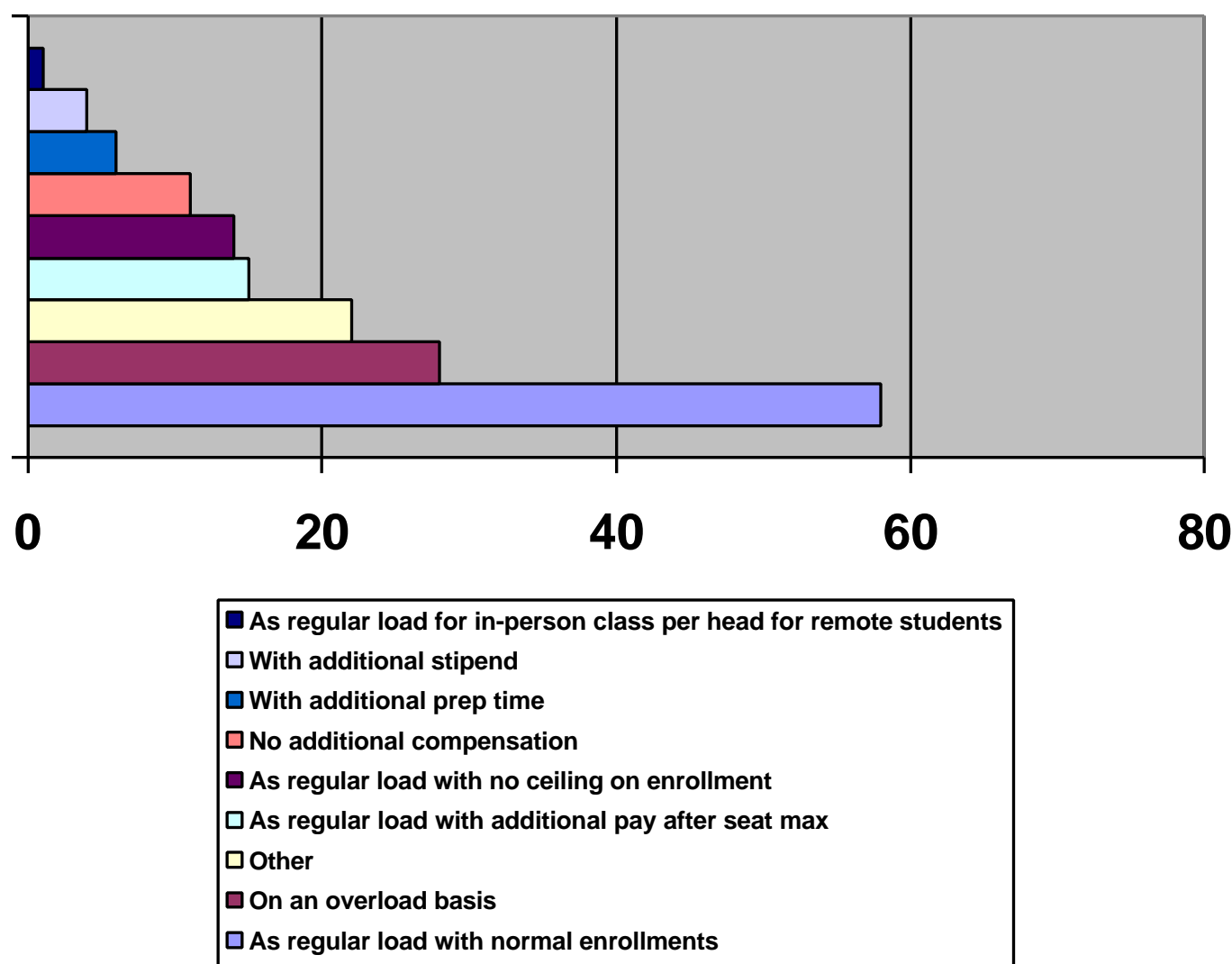

Note: Pre-packaged defined as asynchronous video and audio $\mathrm{N}=116$

Figure 2: Full-time Faculty Compensation--Prepackaged Courses

For live interactive courses, the results were similar. The modem-based courses have fewer numbers of respondents, but show a similar tendency towards a regular load/overload compensation pattern.

Using categories similar to the ITC survey, the NEA [14] data in Figure 3 show similar compensation patterns for all institutions with no distinction among technology typology: 


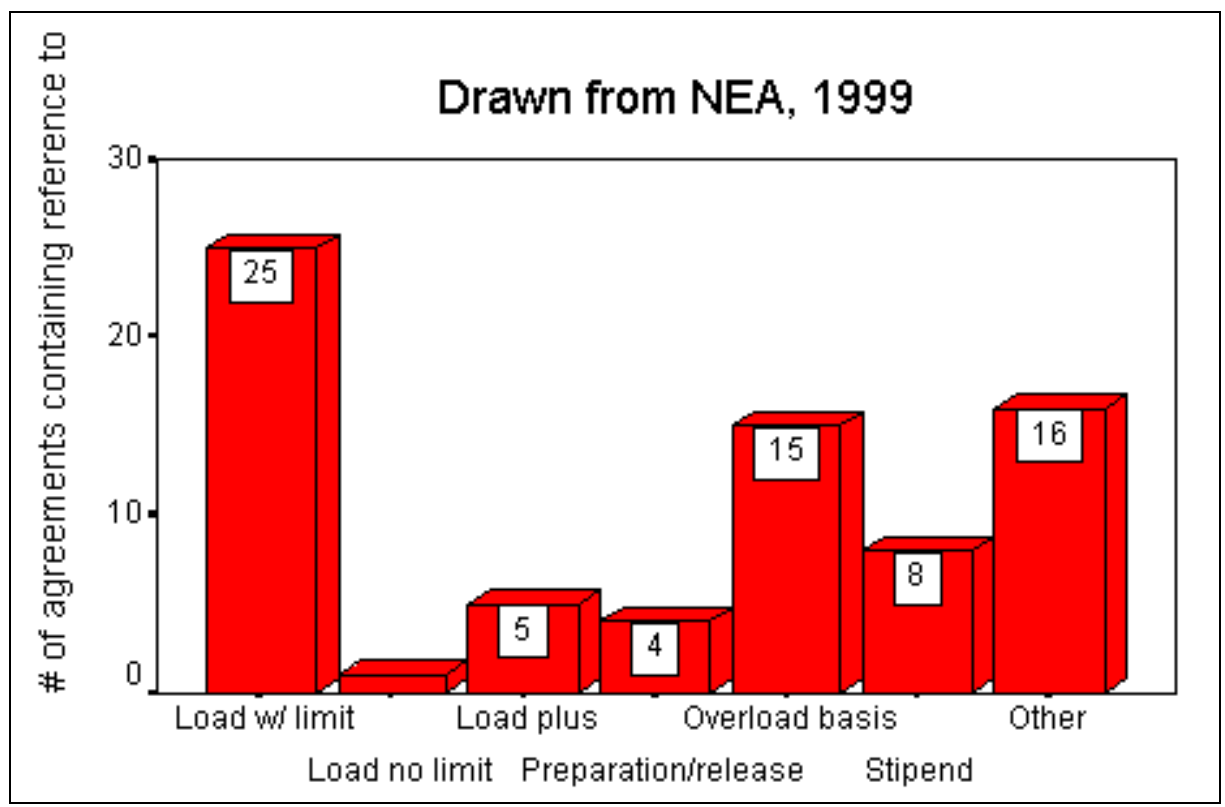

Note: Load w/limit: Regular teaching load with regular enrollment limits Load no limit: Regular teaching load with no enrollment limits Load plus: Regular teaching load with per/enrollment over limit extra pay Other: Primarily contracts stating task force/committee formation

Figure 3. Faculty Compensation--Distance Learning Courses.

Two-year institutions tend more to use load plus extra compensation over enrollment limit (5:0) and to allow release or preparation time more than 4-year counterparts (4:0).

The Primary Research Group [3] found an increase in payment to faculty for course development from $42.5 \%$ in 1997 , to $73 \%$ in 1998 as shown in Table 4 [ $\underline{3}$ (p. 98)].

\begin{tabular}{|l|c|c|}
\hline & Yes & No \\
\hline All colleges & $73 \%$ & $27 \%$ \\
\hline
\end{tabular}

Table 4: Percentage of Distance Learning Programs That Compensate Instructors for the Development of Technology Based Lessons.

However, it should be noted that "compensate" is not defined and load or overload payment might be considered compensation by some of the institutions in the survey.

\section{Collective Bargaining}

The impact of collective bargaining on the type of payment is shown in the ITC survey in Table 4 [13 (p. 25)]: 


\begin{tabular}{|l|c|c|}
\hline & Administrative Contract & Collective Bargaining \\
\hline No additional compensation & $83 \%$ & $17 \%$ \\
\hline With additional stipend & $18 \%$ & $82 \%$ \\
\hline On a overload basis & $62 \%$ & $38 \%$ \\
\hline With additional preparation time & $73 \%$ & $27 \%$ \\
\hline
\end{tabular}

Table 5. Administrative Contract vs. Collective Bargaining.

Collective bargaining agreements show a union preference for receiving an additional stipend over additional preparation time.

\section{Indirect Compensation}

Forms of indirect compensation include royalty arrangements, professional recognition, and training, and.

\section{a. Royalty/Intellectual Property Rights}

Intellectual property rights are probably the most important aspect of compensation because they could lead to significant long-term income for faculty. In the ITC survey shown in Figure 4 [13 (p. 32)], the largest majority of respondents stated that the institution held the intellectual property rights to distance learning courses.

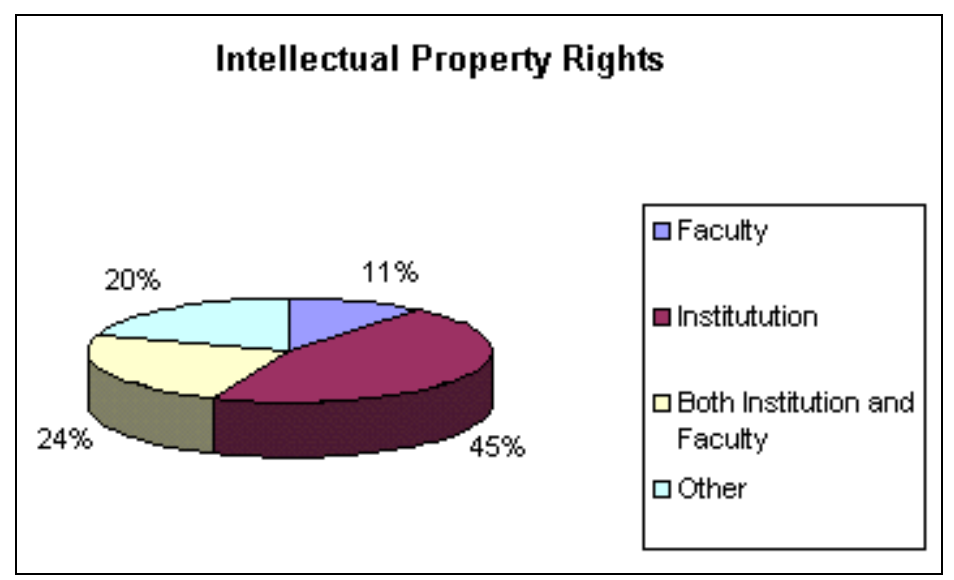

Figure 4. Intellectual Property Rights Ownership.

Only $11 \%$ responded that the faculty member owned the course material.

The survey of NEA agreements with contract language about intellectual property rights for the creation of distance learning courses is shown in Figure 5 [14]: 


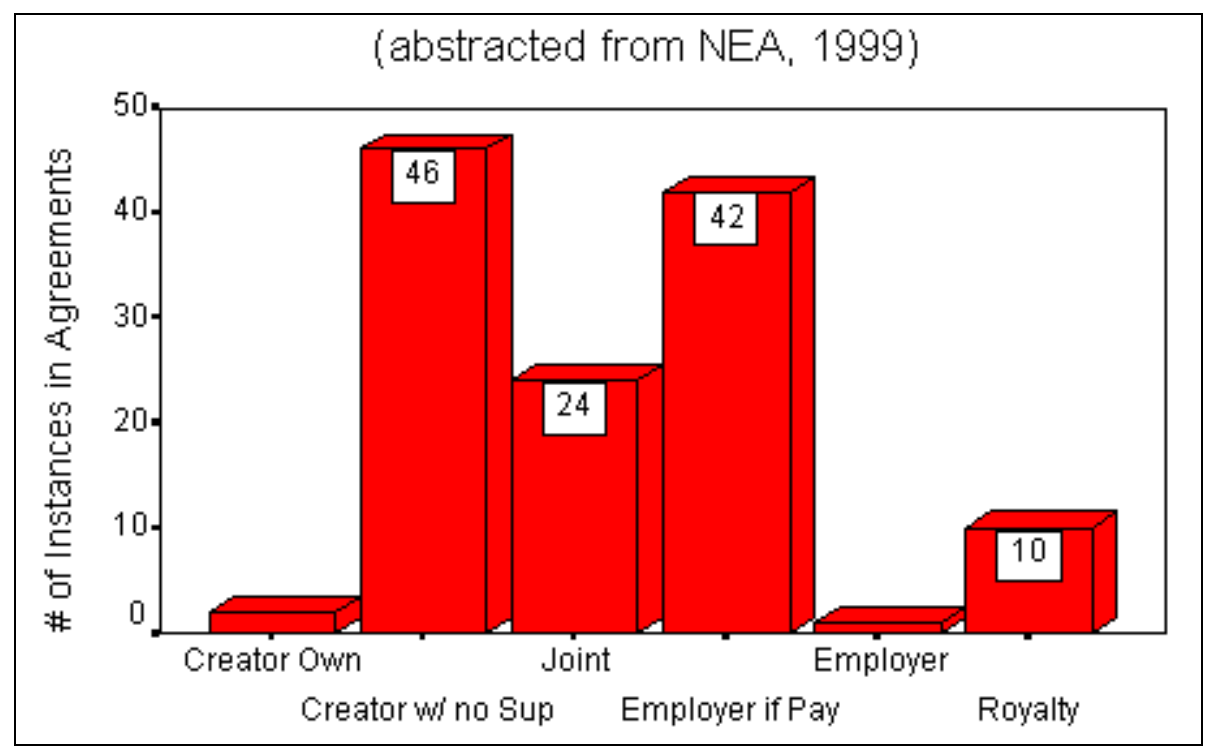

Note: Creator Own: Phrase used referring to faculty outright ownership Creator w/ no Sup: If faculty create course without university support, faculty owns Joint: Reference to some sort of joint ownership between university and faculty Employer if Pay: If university pays for instruction or development, University owns Employer: University owns Royalty: Some sort of royalty structure for faculty mentioned with percentage of income paid over time.

Figure 5. Ownership of Distance Learning--Intellectual Property.

One can see from Figure 5 that the "creator with no institutional support" and "employer own if paying for services" are the two most common phrase occurrences in the agreement group. It should be noted that these two phrases are complementary to some degree, and in fact it was common for both to be mentioned in the same agreement. In these agreements, it is understood that if a faculty member develops a distance learning course on his or her own, ownership goes to the creator. Conversely, if the university pays a faculty member for either teaching or developing a distance learning course, the university owns the course. Most significantly, and surprising, were the low number of instances in which royalty arrangements for the faculty member occurred in the agreements.

Five of the universities left intellectual copyright issues up to individual negotiation, two deferred to general university policy, and six mentioned forming committees to study the question. Fouryear institutions tended to form committees more $(4: 2)$, and defer to university policy $(2: 0)$. Two-year institutions tend more to have royalty structures $(8: 2)$ and to leave royalty questions up to individual negotiation $(4: 1)$.

\section{b. Recognition/Promotion}

Employee recognition was only slight for faculty who teach or create distance learning courses according to the ITC survey shown in Table $6[13$ (p.31)]. 


\begin{tabular}{|l|c|c|c|c|}
\hline & Live Interactive & Prepackaged & Modem-based & Print-based \\
\hline Merit Pay & 1 & 1 & 1 & 1 \\
\hline Promotion & 1 & 2 & 2 & 2 \\
\hline Tenure & 1 & 2 & 2 & 2 \\
\hline None & 51 & 87 & 15 & 16 \\
\hline Other & 10 & 8 & 2 & 0 \\
\hline
\end{tabular}

Note: Live Interactive: Two-way or one-way video, synchronous delivery

Pre-packaged: Telecourses on cable, video cassette, audio cassette, asynchronous

Modem-based: Computer-based using the Internet

Print-based: Majority of course delivered through print

\section{Table 6. Methods for Employee Recognition.}

\section{c. Training}

Professional development and training may be considered as part of the compensation and benefits of employment. The ITC survey shown in Figure 6 [1수 (p. 34)] found 43\% provided no training for distance learning instruction.

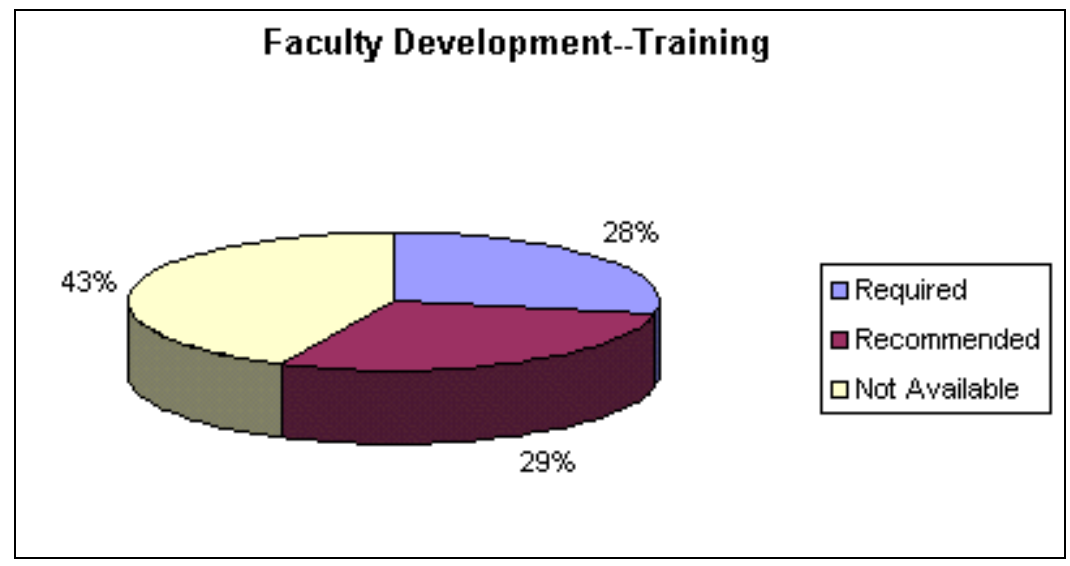

Figure 6. Faculty Development-Training.

Instructional design assistance, which would be considered as more in-depth training and assistance, is not offered by $80 \%$ of the respondents as shown in Figure 7 [13 (p. 36)]. 


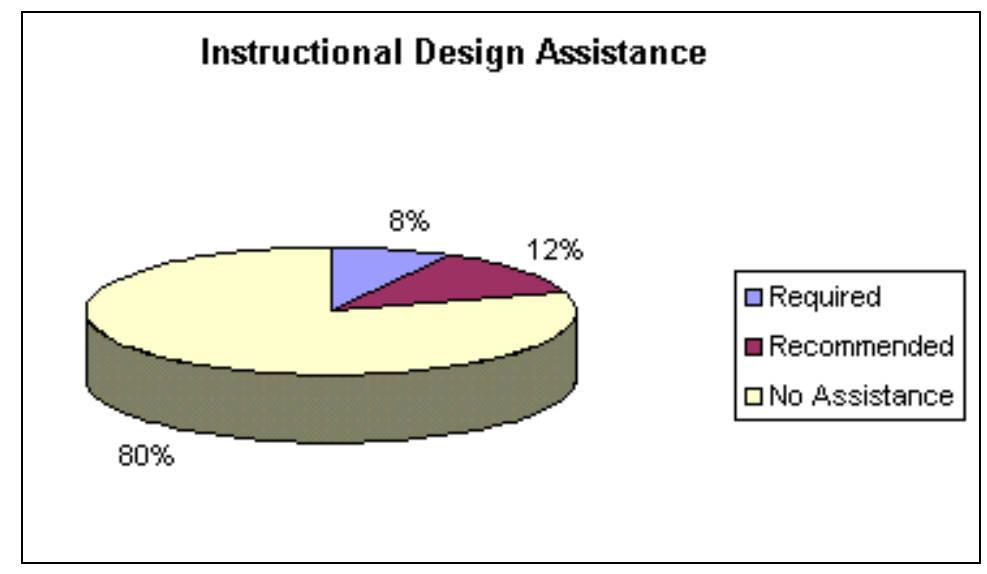

Figure 7. Faculty Development--Instructional Design Assistance.

However, it should be noted that the respondents to the ITC survey may not in fact be developing course materials, but instead using licensed material from external sources. In the NEA group of contracts with clauses dealing with distance learning, 8 out of 64 either require or provide training to faculty for distance learning (not defined as either for development or teaching). Two-year institutions tend more to provide training to faculty $(7: 1)$.

Although the data may reflect a difference in how the questions were phrased, Table $7[3$ (p. 98)] shows that the Primary Research Group found $60 \%$ of those surveyed required faculty training-an increase of $20 \%$ over the previous year.

\begin{tabular}{|l|l|l|}
\hline & Yes & No \\
\hline All colleges & $60 \%$ & $40 \%$ \\
\hline
\end{tabular}

Table 7. Percentage of Distance Learning Programs Whose Instructors Are Required To Undergo Formal Training In Distance Learning.

\section{CONCLUSION}

Obviously, the policies and practices of distance learning in America are changing quickly as evidenced by both the numerous references to task forces and committees formed and the variety of institutional approaches to faculty agreements. However, the data does give one a fairly clear indication of developing patterns showing a tendency towards treating distance learning courses as regular load for faculty and in not including a royalty structure in these agreements. Although there is some conflict in the data over the trends for compensation of faculty in the form of course development fees and training, the most important areas of compensation are direct payment for teaching courses and indirect royalty payments.

This investigation of the current data indicates that in America thus far the two basic strategies for achieving increased productivity (capital for labor, and labor for labor) are in early stages of implementation. In terms of direct compensation, one source [ $\underline{3}$ ] has found a decrease in the percentage of faculty pay in the overall distance learning budget, at $31.72 \%$ for 1998 , down from $37.21 \%$ in 1997. In terms of indirect compensation, a systematic restructuring of the work of faculty into discrete tasks such as is done at the British Open University is thus far only occurring at non-traditional institutions such as the University of Phoenix. While it is unlikely that this kind of division of faculty labor will occur in the immediate future at traditional institutions, 
replacement of expensive faculty may instead occur through the general increased use of parttime or adjunct faculty, as documented in Finkelstein, Seal and Schuster [16]. Indeed, the Primary Research Group [ $[3$ ] found an increase in the use of adjunct faculty who teach distance learning courses from a mean average of $27.34 \%$ in 1997 to $34.16 \%$ in 1998 . In this way, a faculty for cheaper labor switch seems to be occurring in a limited manner.

\section{REFERENCES}

1. National Center For Education Statistics, Statistical Analysis Report: Distance Education in Higher Education Institutions, U.S. Department of Education, 1997.

http://nces.ed.gov/pubs98/distance/index.html

2. Maitland, C., and Rhoades, G., Technology Issues in Bargaining: The New Unionism, In The NEA 1999 Almanac of Higher Education, Washington, D.C., National Education Association, 1999.

3. Primary Research Group, Inc., The Survey of Distance Learning Programs in Higher Education: 1999 Edition, New York, 1999.

4. UCEA, Independent Study Catalog, Washington, D.C., University Continuing Education Association, 1998.

5. Bates, A. W., Technology, Open Learning and Distance Education, London, Routledge, 1995.

6. Daniel, J. S. Mega-universities and Knowledge Media: Technology Strategies for Higher Education. London, Kogan Page Limited, 1998.

7. Massy, W. F., and Zemsky, R., Using Information Technology to Enhance Academic Productivity, A Report from a June 1995 Educom Roundtable, EDUCAUSE, 1995.

http://www.educause.edu/nlii/keydocs/massy.html

8. Twigg, C. A., Academic Productivity: The Case for Instructional Software, A Report from the Broadmoor Roundtable, Colorado Springs, Colorado, July 24-25, 1996. EDUCAUSE http://www.educause.edu/nlii/keydocs/broadmoor.html

9. Metlitzky, L., Bridging the Gap for the Mainstream Faculty: Understanding the use of technology in instruction Unpublished dissertation. Claremont, CA, Claremont Graduate University, 1999.

10. Jewett, F., A Framework for the Comparative Analysis of the Costs of Classroom Instruction Vis-ÀVis Distributed Instruction, Presented at Executive Forum on Managing the Cost of Information Technology in Higher Education sponsored by the NJICTL, Princeton, NJ, April 16, 1999. http://www.shu.edu/depts/itcosts/papers.html

11. Snowden, B. L. and Daniel, J. S., The Economics and Management of Small Post-secondary Distance Education Systems, Distance Education. 1, 1, 68-91, 1980.

12. Arvan, L., Ory, J.C., Bullock, C.D., Burnaska, K.K., Hanson, M., The SCALE Efficiency Projects. Journal of Asynchronous Learning Network, Volume 2, Issue 2, September 1998. http://www.aln.org/alnweb/journal/vol2 issue2/arvan2.htm

13. Edwards, R. and Minich, E., Faculty Compensation and Support Issues in Distance Education, Washington, DC, The Instructional Telecommunication Council, 1998.

14. NEA, Bargaining Technology Issues in Higher Education: NEA Higher Education Contract Analysis System (HECAS) 1998-99 version, Higher Education Research Center, 1999.

15. Green, K. C., Campus Computing 1998: The Ninth National Survey of Desktop Computing and Information Technology in Higher Education, Encino, CA, The Campus Computing Project, 1999.

16. Finkelstein, M. J., Seal, R. K. and Schuster, J. H., The New Academic Generation: A Profession in Transformation, Baltimore, MD, Johns Hopkins University, 1998.

\section{ABOUT THE AUTHOR}

Gary A. Berg is Director of Extended Education at Chapman University and has written articles on distance learning and new media for WebNet Journal, Education at a Distance Journal, AFT Now, Journal of Educational Multimedia and Hypermedia and others. This article is based on 
work done in conjunction with current research by Jack H. Schuster, professor at Claremont Graduate University, and Martin J. Finkelstein, professor at Seton Hall University, on the American academic profession funded by the Alfred P. Sloan Foundation and the Andrew W. Mellon Foundation. 